\title{
Effect of salinity and pH on growth, phycoerythrin, and non-volatile umami taste active compound concentration of Rhodomonas salina using a D-optimal design approach
}

\author{
Christos Latsos $^{1}$ (D) . Georgios Bakratsas ${ }^{1} \cdot$ Tanja Moerdijk $^{1} \cdot$ Jasper van Houcke $^{1} \cdot$ Klaas R. Timmermans $^{1,2}$
}

Received: 14 April 2021 / Revised and accepted 16 June 2021 / Published online: 21 July 2021

(c) The Author(s) 2021

\begin{abstract}
The cryptophyte Rhodomonas salina is widely used in aquaculture due to its high nutritional profile. This study aims to investigate the effect of salinity and $\mathrm{pH}$ on the growth, phycoerythrin concentrations, and concentrations of non-volatile umami taste active compounds of $R$. salina, using a design of experiment approach. Rhodomonas salina was cultivated in a flat-panel photobioreactor in turbidostat mode in a range of salinity $(20-40 \%)$ and $\mathrm{pH}(6.5-8.5)$. The strain was able to grow steadily under all conditions, but the optimal productivity of $1.17 \mathrm{~g}$ dry weight $\mathrm{L}^{-1}$ day ${ }^{-1}$ was observed in salinity 30 $\% o$ and $\mathrm{pH}$ 7.5. The phycoerythrin concentration was inversely related to productivity, presenting higher values in conditions that were not optimal for the growth of $R$. salina, $7 \%$ of dry weight at salinity $40 \%$, and $\mathrm{pH} 8.5$. The identification of the umami taste of $R$. salina was based on the synergistic effect of umami compounds 5 '-nucleotides (adenosine 5 '-monophosphate, guanosine 5'-monophosphate, inosine 5'-monophosphate) and free amino acids (glutamic and aspartic acids), using the equivalent umami concentration (EUC). The results indicated that an increase in $\mathrm{pH}$ induces the accumulation of 5'-nucleotides, resulting in an EUC of $234 \mathrm{mg} \mathrm{MSG} \mathrm{g}^{-1}$ at a salinity of 40 and $\mathrm{pH}$ 8.5. The EUC values that were observed in $R$. salina were higher compared to other aquatic animals, a fact that makes $R$. salina promising for further research and application in the food and feed sectors.
\end{abstract}

Keywords Cryptophyceae $\cdot$ Microalgae production $\cdot$ Biomass productivity $\cdot$ Photobioreactors $\cdot$ Free amino acid $\cdot$ Umami taste

\section{Introduction}

Marine microalgae have a wide range of commercial and industrial applications (Spolaore et al. 2006; Chu 2013; Khatoon and $\mathrm{Pal}$ 2015). They have been introduced to the human diet for thousands of years and have been utilised as high-value food (Borowitzka 1998; Varfolomeev and Wasserman 2011; Hudek et al. 2014). In the last 20 years, the most dominant microalgae in food and nutraceutical applications are Spirulina, Chlorella, Dunaliella, and Haematococcus due to their biochemical

Christos Latsos

christos.latsos@hz.nl

1 HZ University of Applied Sciences, P.O. Box 364, 4380 AJ Vlissingen, The Netherlands

2 Department of Estuarine and Delta Systems, Netherlands Institute for Sea Research (NIOZ), P.O. Box 140, Royal 4400 AC Yerseke, The Netherlands characteristics and nutritional benefits (Bishop and Zubeck 2012; Koyande et al. 2019).

Except for the biochemical composition, the flavour is also an important criterion for the use of microalgae in the food sector. Free amino acids (FAAs) are associated with the characteristic taste of marine food. FAAs contribute to different degrees to the five primary tastes of food (sweetness, sourness, saltiness, bitterness, and umami) according to their side chains (Shallenberger 1993; Kawai et al. 2002). Alanine and glycine, for example, have a pleasant sweet taste and significant umami enhancement. It is reported that the sweet taste of lobster and crab is mainly influenced by glycine, while the characteristic taste of sea urchin is due to methionine (Nishimura and Kato 2009). The biochemical composition and sensory characteristics of oysters are attributed to the dietary composition, indicating that the flavour characteristics of algae can be carried through to the fed organism (van Houcke et al. 2017). 
Although not all FAAs have a strong taste themselves, their taste can be strengthened by the presence of other compounds, such as nucleotides (Yamaguchi et al. 1971). Nucleotides are involved in producing the umami taste (Fuke and Konosu 1991). Adenosine 5'-monophosphate (AMP) is related to the sweet and umami taste of scallops (Watanabe et al. 1990). Inosine 5'-monophosphate (IMP) and guanosine 5'-monophosphate (GMP) are connected with the enhancement of the umami taste of monosodium glutamate (MSG) (Fuke and Ueda 1996). There is a synergistic interaction between AMP-IMP, MSG-IMP, and MSG-GMP in intensifying umami taste (Ninomiya et al. 1992; Fuke and Ueda 1996; Yamaguchi 1996). The equivalent umami concentration (EUC) is used to determine the synergistic effect, as a combination of MSG-like AAs (glutamic acids and aspartic acid) and nucleotides (Mau 2005; Liu and Qiu 2016; Zhao et al. 2016; Liu et al. 2019).

Rhodomonas salina has been reported as promising feed for many aquaculture species (Guevara et al. 2011; Riisgård et al. 2011; Gonzalez Araya et al. 2012; Arndt and Sommer 2014). Besides the common photosynthetic pigments, $R$. salina is rich in phycoerythrin, a water-soluble, coloured, and fluorescent protein that absorbs light at $545 \mathrm{~nm}$ and has an emission peak at $578 \mathrm{~nm}$ (Doust et al. 2006). Phycoerythrin can be used as a food colourant and is linked to anti-parasitic and anti-tumour activities (Coelho et al. 1998; Sudhakar et al. 2015).

Many studies have declared a variability in microalgae biochemical composition depending on seasonality, nutrients, light quantity and quality, salinity, etc. (De Oliveira et al. 1999; Renaud et al. 1999; Thompson 1999; Fábregas et al. 2002; Mulders et al. 2014; Latsos et al. 2020, 2021). Microalgal biochemical composition and amino acid profile are species-dependent (Brown et al. 1997). Microalgae can modify their growth and their biochemical composition under different environmental factors (AL-Qasmi et al. 2012). This modification and variation of growth and biochemical composition represent a trade-off between the quantity and quality of microalgae.

$\mathrm{pH}$ determines the solubility and availability of $\mathrm{CO}_{2}$ and has a significant influence on microalgae metabolism (Chenl and Durbin 1994). This influence makes pH one of the most critical environmental conditions for microalgae cultivation. Salinity is another factor that varies in the environment. In response to salinity changes, microalgae accumulate small molecules to overcome osmotic stress (Richmond 2004). Each microalgal species has an optimal range of $\mathrm{pH}$ and salinity for growth. In variations of environmental conditions out of these ranges, microalgae may accumulate potentially harmful reactive oxygen species (ROS). ROS can produce cellular damage if they overcome the antioxidant activity of the algae (Neelam and Subramanyam 2013).
The phycoerythrin production in different salinity environments has not been examined extensively. Jepsen et al. (2019) reported that $R$. salina could grow in a wide range of salinity (0-65\%o), but the effect on phycoerythrin was not determined. Marraskuranto et al. (2018) investigated the phycoerythrin concentration of $R$. salina, in two different salinities, 33\%o and 50\%o, obtaining a higher phycoerythrin concentration in salinity of $33 \%$. The effect of salinity and $\mathrm{pH}$ on the FAA profile has not been investigated previously for $R$. salina. This study aims to investigate the effect of salinity and $\mathrm{pH}$ on $R$. salina growth, phycoerythrin, and FAA concentrations in a D-optimal design. From the FAA and nucleotide concentrations, the taste and use of $R$. salina in the food industry can be evaluated.

\section{Materials and methods}

\section{Strain and pre-culture conditions}

The marine cryptophytic microalgae Rhodomonas salina CCMP1319 was supplied by the Dutch aquaculture industry, as a strain used in a commercial application. Rhodomonas salina was pre-cultured in pre-sterilised $\left(20 \mathrm{~min}\right.$ at $\left.120^{\circ} \mathrm{C}\right)$ $300 \mathrm{~mL}$ Erlenmeyer flasks in 20 times concentrated nutrients of filtered $(0.2 \mu \mathrm{m}$ pore size) $\mathrm{f} / 2$ medium (Guillard and Hargraves 1993). The final concentration of $\mathrm{NaNO}_{3}$ and $\mathrm{NaH}_{2} \mathrm{PO}_{4} \mathrm{H}_{2} \mathrm{O}$ were $0.75 \mathrm{~g} \mathrm{~L}^{-1}$ and $50 \mathrm{mg} \mathrm{L}^{-1}$, respectively, with a salinity of $30 \mathrm{~g} \mathrm{~L}^{-1}$. Cultures were continuously illuminated at a photon flux density (PFD) of $120 \mu \mathrm{mol}$ photons $\mathrm{m}^{-2} \mathrm{~s}^{-1}$ provided by cool white fluorescent tubes. The temperature in the incubator was maintained at $20 \pm 1{ }^{\circ} \mathrm{C}$ and air enriched with $5 \% \mathrm{CO}_{2} \mathrm{v} / \mathrm{v}_{\text {air }}$ was supplied in the headspace of the Erlenmeyer flasks. The growth of the cultures was monitored by measuring the cell abundance with a Coulter counter (Beckman coulter Z1) in order to ensure that the inoculum was in the exponential phase before it was used in the experiments.

\section{Experimental setup}

Rhodomonas salina was continuously cultivated in a flat panel airlift-loop photobioreactor (PBR) (Algaemist-S, Technical Development Studio, Wageningen University, the Netherlands) with $0.4 \mathrm{~L}$ working volume, $14 \mathrm{~mm}$ light path, and $0.028 \mathrm{~m}^{2}$ total illuminated area (Breuer et al. 2013). Warm light was continuously provided by Bridgelux LED lamps (BXRAW1200, Bridgelux, USA) from one side of the Algaemist-S system. Unintentional exposure to other light sources was prevented by a black cover placed on the other side of the reactor. The primary light intensity was initially set at around $100 \mu \mathrm{mol}$ photons $\mathrm{m}^{-2} \mathrm{~s}^{-1}$ after the algae were inoculated to resemble the environment of the orbital 
incubator where the algae grew in the pre-culture phase. Then, the light intensity was raised gradually to $300 \mu \mathrm{mol}$ photons $\mathrm{m}^{-2} \mathrm{~s}^{-1}$, which is reported as non-limiting for $R$. salina (Vu et al. 2016). The temperature was maintained at $22{ }^{\circ} \mathrm{C}$ using a water jacket, attached to the culture compartment of the photobioreactor. Turbidostat mode was applied to ensure stable outgoing light at the rear of the reactor of $15 \mu$ mol photons $\mathrm{m}^{-2} \mathrm{~s}^{-1}$, by diluting the reactor with 20 times concentrated $\mathrm{f} / 2$ medium filtered through a $0.2-\mu \mathrm{m}$ pore filter. $\mathrm{pH}$ was maintained constant by mixing $\mathrm{CO}_{2}$ with the airflow on demand. The $\mathrm{CO}_{2}$ levels in the water were not measured.

\section{Design of experiment}

A D-optimal design of experiment (DoE) approach, created by Design Expert 11 software (StatEase, USA), was followed, with salinity $(20-40 \%$ ) and $\mathrm{pH}(6.5-8.5)$ as factors. A D-optimality was selected to produce a design that best estimates the effect of the factors and is particularly suited for screening studies. Six lack-of-fit points were added to make the design more robust. The centre point, in which the input factors are set in the middle of the highest and lowest values, was performed in triplicate. By performing the centre point in triplicates, the accuracy and reproducibility of the experiments are increased. This approach resulted in 15 experiments, which are illustrated in Table 1.

\section{Culture measurements}

Samples were taken from the PBR on a daily basis and were analysed for basic culture characteristics. Optical density was measured at $750 \mathrm{~nm}\left(\mathrm{OD}_{750 \mathrm{~nm}}\right)$, from which biomass concentration $\left(\mathrm{C}_{\mathrm{x}}\right)$ was calculated (Supplementary data). Cell density and volume was measured in Coulter Counter (Multisizer 3, Beckman Coulter, USA) in the size range 7-14 $\mu \mathrm{m}$. The growth rate $(\mu)$ was calculated when the PBR was running in turbidostat mode as the dilution rate (D) according to Eq. (1), where $V_{H}$ is the harvested volume in a $\Delta t$ period of time and $V_{R}$ the reactor volume:

$\mu=D=\frac{\frac{V_{H}}{\Delta t}}{V_{R}}$

The biomass production rate $\left(r_{x}\right)$ for the turbidostat mode was calculated from the growth rate and the biomass concentration $\left(\mathrm{C}_{\mathrm{x}}\right.$, Eq. (2)):

$r_{x}=\mu \times C_{x}$

The biomass production rate and the absorbed light $\left(\Delta \mathrm{I}_{\mathrm{ph}}=\mathrm{I}_{\mathrm{ph}, \mathrm{in}} \mathrm{I}_{\mathrm{ph}, \text { out }}\right)$ were used for the calculation of biomass yield on light $\left(\mathrm{Y}_{\mathrm{x}, \mathrm{ph}}\right)$ (Eq. (3)). $Y_{x, p h}$ is defined as the biomass concentration that can be produced over a mol of photons:

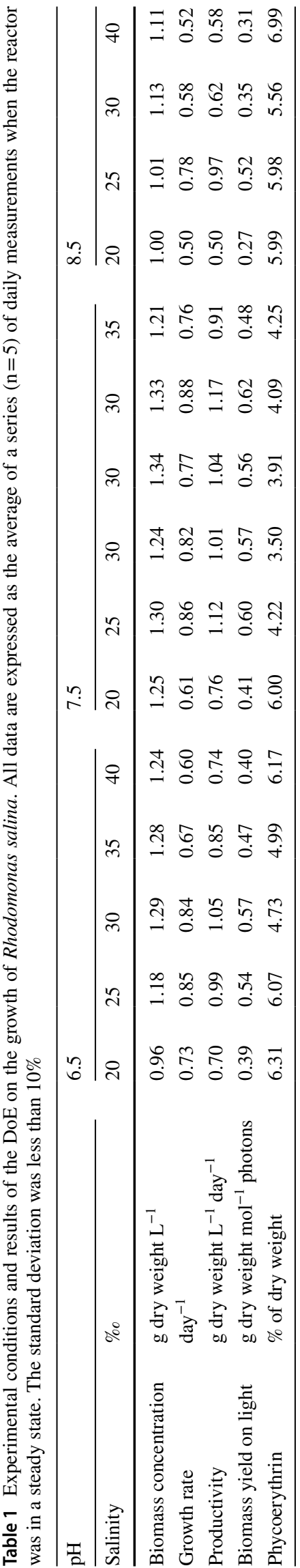




$$
Y_{x, p h}=\frac{r_{x}}{\Delta I_{p h}}
$$

\section{Cellular composition}

\section{Phycoerythrin concentration}

Samples of each experiment were taken for phycoerythrin determination when the culture was in a steady state. The phycobilin pigments were extracted in phosphate buffer by a freeze-thawing process, centrifuged (10 $\mathrm{min}$ at $1153 \mathrm{~g}$ ), and analysed using UV-VIS spectroscopy according to Bennett and Bogorad (1973; Lawrenz et al. 2011). Absorbance at $545 \mathrm{~nm}$ was used after scatter corrected by subtracting the absorbance at $750 \mathrm{~nm}$. Phycoerythrin was calculated in $\mu \mathrm{g}$ $\mathrm{L}^{-1}$ according to Eq. (4):

$P E=\frac{A}{\varepsilon d} \times M W \times \frac{V_{\text {sample }}}{V_{\text {buffer }}} \times 10^{6}$

where $\varepsilon$ is the molar extinction coefficient of phycoerythrin $\left(2.41 \times 10^{6} \mathrm{~L} \mathrm{~mol}^{-1} \mathrm{~cm}^{-1}\right), M W$ is the molecular weight of phycoerythrin $\left(240,000 \mathrm{~g} \mathrm{~mol}^{-1}\right), d$ is the path length in $\mathrm{cm}$, and $V_{\text {sample }}$ and $V_{\text {buffer }}$ are the volumes of the sample and the buffer, respectively.

\section{FAA and nucleotides}

When the PBR was in steady-state, $50 \mathrm{~mL}$ of culture was sampled and concentrated by centrifuging at $1153 \mathrm{xg}$ for $15 \mathrm{~min}$. The supernatant was discarded and $50 \mathrm{~mL}$ of ammonium formate $(0.5 \mathrm{M})$ was added to rinse out the salt and to prevent osmotic shock. This rinsing was repeated twice. Then, the biomass was lyophilised and stored at $-20{ }^{\circ} \mathrm{C}$ before the FAA and nucleotide analysis. FAA and nucleotides were extracted and analysed according to MoerdijkPoortvliet et al. (under review for Food Chemistry). In brief, $15 \mathrm{mg}$ of biomass and $5 \mathrm{~mL}$ Milli-Q were homogenised and extracted for $15 \mathrm{~min}$ at $35{ }^{\circ} \mathrm{C}$ followed by centrifugation (3000 rpm, $20 \mathrm{~min}$ ). The supernatant was taken and an acid precipitation step was performed to remove contaminants. For FAA, an additional purification step was performed using DOWEX 50WX8 cation exchange resin. FAA and nucleotide samples were analysed by means of high-performance liquid chromatography (HPLC) using a DIONEX Ultimate 3000 HPLC system. For FAA analysis, the HPLC was equipped with an Agilent InfinityLab Poroshell 120 HPH-C18 column $(100 \times 4.6 \mathrm{~mm} ; 2.7 \mu \mathrm{m}$, matching guard column $(5 \times 4.6 \mathrm{~mm} ; 2.7 \mu \mathrm{m})$, and a fluorescence detector (FLD 3100)). For nucleotide analysis, the HPLC was equipped with a SIELC PrimeSep D mixed-mode column
$(150 \times 4.6 \mathrm{~mm} ; 5 \mu \mathrm{m})$ with a corresponding guard column $(10 \times 4.6 \mathrm{~mm} ; 5 \mu \mathrm{m})$ and an ultraviolet detector (DAD 3000).

\section{Equivalent umami concentration}

The umami estimation can be determined based on the concentration of monosodium glutamate $\left(\mathrm{mg} \mathrm{MSG} \mathrm{g}^{-1}\right.$ ), which is equivalent to the umami intensity. The synergy effect between the mixture MSG-like AAs and 5'-nucleotides is represented by Eq. (5) (Yamaguchi et al. 1971):

$Y=\sum a_{i} b_{i}+12.18\left(\sum a_{i} b_{i}\right)\left(\sum a_{j} b_{j}\right)$

where $Y$ is the EUC (mg MSG g $\left.{ }^{-1}\right) ; a_{i}$ is the concentration $\left(\mathrm{mg} \mathrm{g}^{-1}\right)$ of each umami AA (aspartic or glutamic acid); $a_{j}$ is the concentration $\left(\mathrm{mg} \mathrm{g}^{-1}\right)$ of each umami $5^{\prime}$-nucleotide (IMP, GMP, or AMP); $b_{i}$ is the relative umami concentration (RUC) for each umami AA to MSG (1 for glutamic acid, and 0.077 for aspartic acid); and $b_{j}$ is the RUC for each umami 5'-nucleotide to IMP ( 1 for IMP, 2.3 for GMP, and 0.18 for AMP). A total of 12.18 is the synergistic constant based on the concentration of $\mathrm{mg} \mathrm{g}^{-1}$ used.

\section{Data analysis and statistics}

All data measurements are shown as average $( \pm \mathrm{SD})$ of 5 daily measurements when the reactor was in a steady-state (stable dilution rate). Data were tested for normal distribution (Kolmogorov-Smirnoff goodness of fit test). For the growth rate, productivity, biomass yield on light, and $\mathrm{PE}$ data, different models were able to fit the data. The quadratic model was chosen, because this model was adding the most significant explanation of the data compared to the other models (lowest sequential p-value, highest lack of fit $p$-value), with an ANOVA test to imply the significance of the model. The quadratic model looks to second-order terms in addition to the linear blending model. Statistical analysis was performed using SPSS 25.0 statistical package (SPSS Inc, USA) and Design Expert 11 software (StatEase, USA).

\section{Results}

\section{Growth rate, biomass concentration, productivity, and yield on light}

The growth rate of $R$. salina was affected more by the $\mathrm{pH}$ $(\mathrm{p}=0.038)$ than by salinity. The highest observed growth rate was $0.88 \mathrm{day}^{-1}$ at one of the triplicates of the centre point of D-optimal design ( $30 \%$ and $7.5 \mathrm{pH}$ ). The centre point of the D-optimal design was reproducible with a biomass concentration of $1.3 \pm 0.04 \mathrm{~g} \mathrm{~L}^{-1}$, a growth rate of $0.82 \pm 0.04 \mathrm{day}^{-1}$, a biomass productivity of $1.07 \pm 0.07 \mathrm{~g}$ 
$\mathrm{L}^{-1} \mathrm{day}^{-1}$, and a biomass yield on light of $0.58 \pm 0.03 \mathrm{~g} \mathrm{~mol}$ photon $^{-1}$. The maximum growth rate was predicted by the model in $28.2 \%$ and $6.9 \mathrm{pH}$, equal to $0.85 \mathrm{day}^{-1}$ $(p=0.0084$, Fig. 1A). Above $7.5 \mathrm{pH}$, the growth rate was reduced, with an observed minimum at $\mathrm{pH} 8.5$ of $0.5 \mathrm{day}^{-1}$.

The biomass concentration was stable during each experiment, due to the turbidostat sensor. However, our results indicate that the biomass concentration is affected by both salinity and $\mathrm{pH}(\mathrm{p}=0.04)$. The lowest biomass concentration was observed at $20 \%$ and $\mathrm{pH} 6.5,0.96 \mathrm{~g} \mathrm{~L}^{-1}$, while the highest biomass concentration was measured in the centre point of the design $(30 \%$ and $7.5 \mathrm{pH}), 1.30 \pm 0.04 \mathrm{~g} \mathrm{~L}^{-1}$. According to the model, and illustrated by Fig. 1B, the maximum biomass concentration is predicted at $34.9 \%$ salinity and $7.2 \mathrm{pH}$, which is equal to $1.33 \mathrm{~g} \mathrm{~L}^{-1}(p=0.009)$.

As a combination of growth rate and biomass concentration, the biomass productivity reported the highest value in one of the centre points ( $30 \%$ and $7.5 \mathrm{pH}$ ), $1.17 \mathrm{~g}$ $\mathrm{L}^{-1} \mathrm{day}^{-1} \cdot \mathrm{pH}$ had a significant influence on the biomass productivity $(\mathrm{p}=0.04)$, illustrating the lowest values at $\mathrm{pH}$ 8.5 and the edges of the salinity range, 20 and $40 \%, 0.5$, and $0.58 \mathrm{~g} \mathrm{~L}^{-1} \mathrm{day}^{-1}$, respectively (Fig. 2). After taking into account all the centre points with average biomass productivity of $1.07 \mathrm{~g} \mathrm{~L}^{-1} \mathrm{day}^{-1}$, the model predicts maximum biomass productivity in $29.7 \%$ and $7.2 \mathrm{pH}, 1.11 \mathrm{~g} \mathrm{~L}^{-1}$ day $^{-1}$ $(p=0.0056)$.

The biomass yield on light followed the same pattern as the productivity. The biomass yield on light was significantly affected by the $\mathrm{pH}(p=0.037)$, presenting higher values at 7.5 and lower at 8.5. The highest measured biomass yield on light was at pH 7.5 and salinity $30 \%$, while according to the quadratic model, the maximum biomass yield on light is predicted at pH 7.2 and salinity of $29.5 \%$ ( $p=0.005)$ (Fig. 1C).

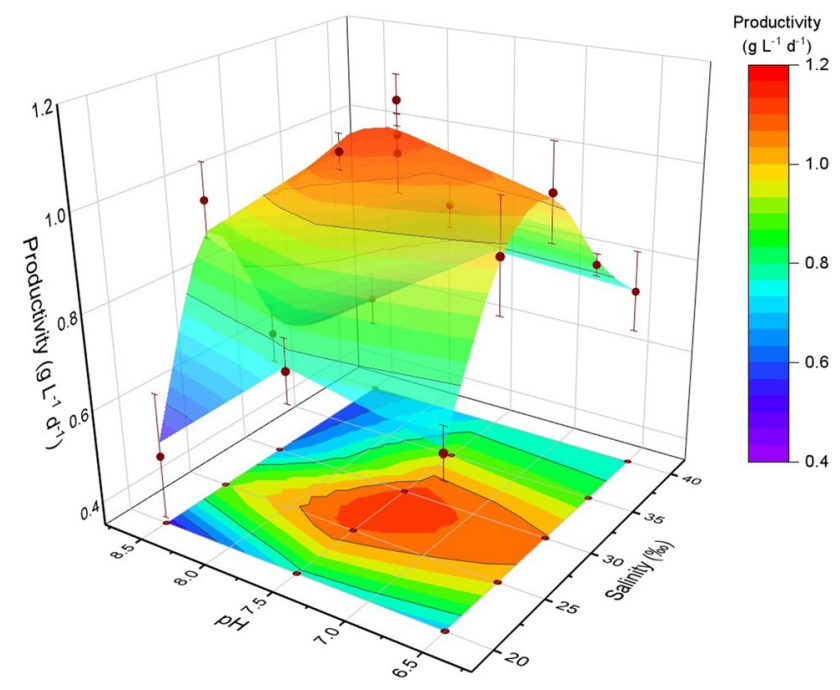

Fig. 2 Effect of salinity (\%o, x-axis) and $\mathrm{pH}$ (y-axis) on growth (z-axis, g dry weight $\mathrm{L}^{-1} \mathrm{day}^{-1}$ ) of $R$. salina. Individual experimental data points are illustrated by red dots

\section{Cellular composition}

\section{Phycoerythrin}

From our experimental data, the significant effect of $\mathrm{pH}$ and salinity on the phycoerythrin concentration of $R$. salina was estimated and is illustrated in Fig. $3(p<0.001)$. The highest phycoerythrin concentration was observed in salinity of $40 \%$ and $\mathrm{pH}$ of 8.5 , with $6.99 \%$ of dry weight. The lowest concentration was detected in the triplicates of the centre point of the D-optimal design, $3.82 \pm 0.27 \%$ of dry weight.
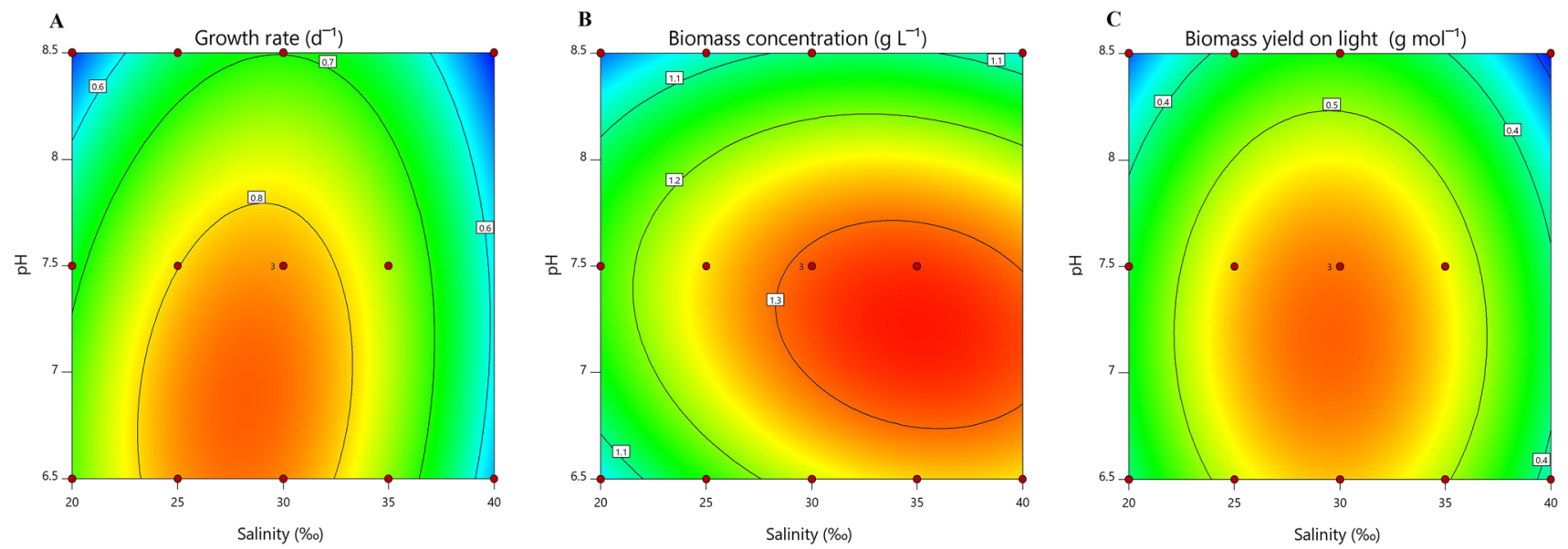

Fig. 1 Effect of salinity (\%o, x-axis) and $\mathrm{pH}$ (y-axis) on $(\mathbf{A})$ growth rate $\left(\mathrm{day}^{-1}\right),(\mathbf{B})$ biomass concentration $\left(\mathrm{g}_{\text {dry weight } \mathrm{L}^{-1} \text { day }}{ }^{-1}\right)$, and $(\mathbf{C})$ biomass yield on light (g dry weight $\mathrm{mol}^{-1}$ photons) of $R$. salina. Individual experimental data points are illustrated by red dots 


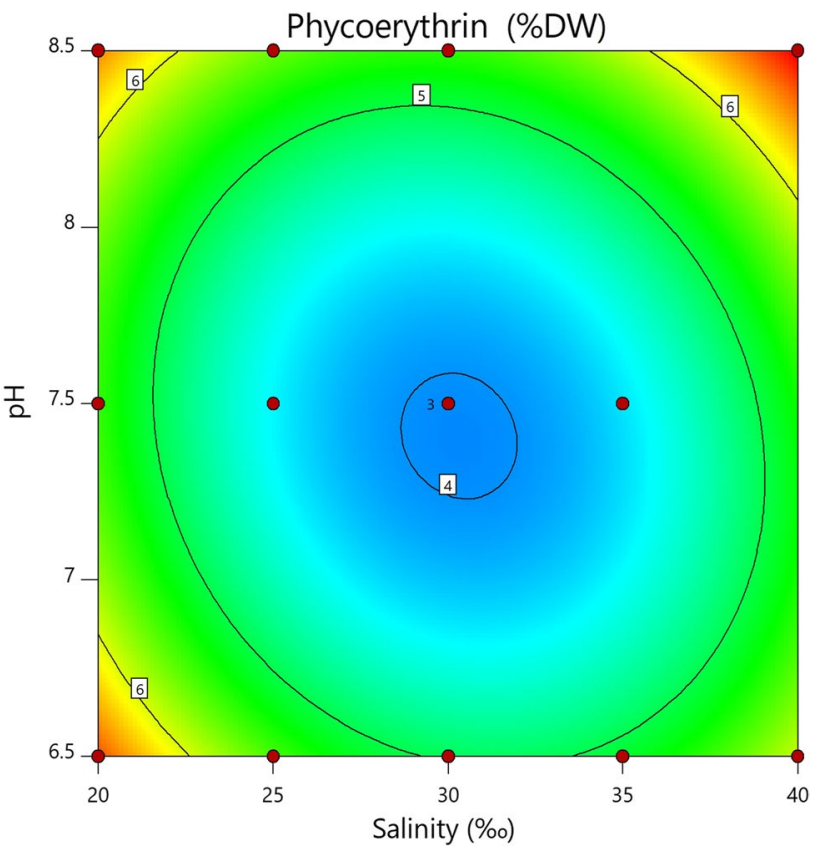

Fig. 3 Phycoerythrin concentration (\% of dry weight) of $R$. salina as a function of salinity (\%o, $\mathrm{x}$-axis) and $\mathrm{pH}$ (y-axis). Individual experimental data points are illustrated by red dots

\section{FAAs, nucleotides, and EUC}

Table 2 summarises the FAA and nucleotide profile of $R$. salina determined under each experimental condition. The main FAAs in $R$. salina were L-glutamic acid (Glu), L-alanine (Ala), L-proline (Pro), and L-arginine (Arg) with a concentration of $18 \%, 16 \%, 14 \%$, and $11 \%$ of total FAA, respectively. The total FAA concentrations vary from 14.29 to $38.34 \mathrm{mg} \mathrm{g}^{-1}$ dry weight. Total FAA concentration increased at $\mathrm{pH} 8.5$ compared to the other two $\mathrm{pH}$ settings. However, this increase was not statistically significant $(p=0.7)$. The highest total FAA concentration was observed in salinity of $30 \%, 28.51 \pm 7.9 \mathrm{mg} \mathrm{g}^{-1}$ dry weight, significantly higher than in the other salinities $(\mathrm{p}=0.022)$. Salinity and $\mathrm{pH}$ also affected the nucleotide profile of $R$. salina. AMP was affected significantly by both salinity

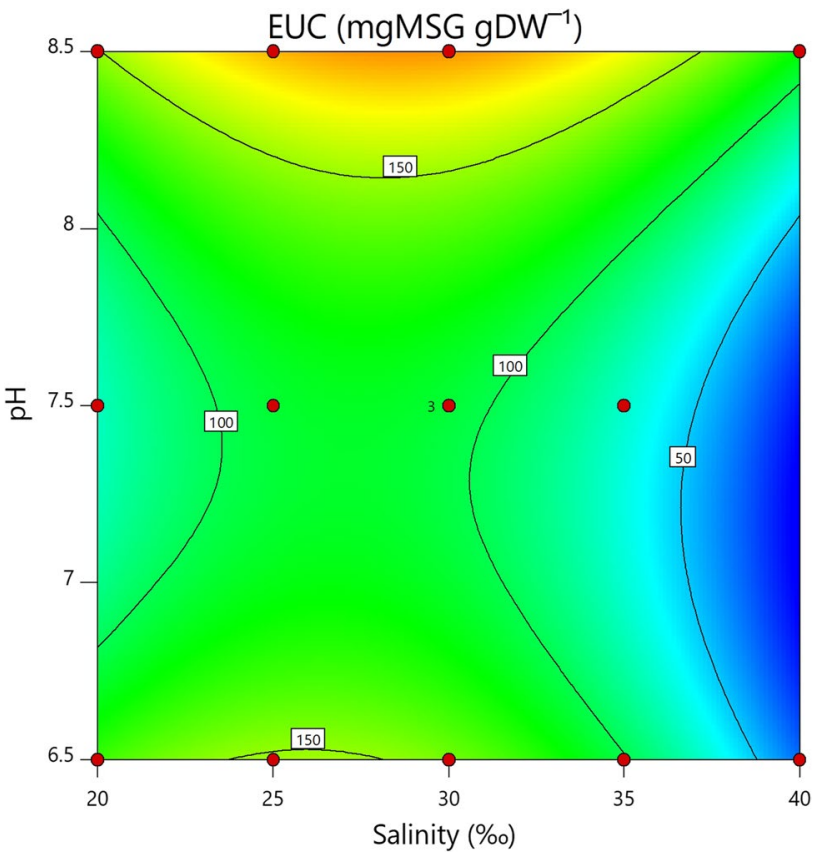

Fig. 4 Equivalent umami concentration (EUC, mg MSG $\mathrm{g}^{-1}$ dry weight) of $R$. salina as a function of salinity (\%o, $\mathrm{x}$-axis) and $\mathrm{pH}$ (y-axis). Individual experimental data points are illustrated by red dots

and $\mathrm{pH}$, with a peak in $25 \%$ and $\mathrm{pH}$ of $8.5,1.26 \mathrm{mg} \mathrm{g}^{-1}$ dry weight ( $p=0.007)$. For GMP and IMP, $\mathrm{pH}$ did not have any significant effect, but in the centre point of salinity (30 $\%$ ), the concentration of both nucleotides was significantly higher compared to the other salinities $(p=0.01)$.

The EUC was calculated from Asn, Glu, AMP, GMP, and IMP concentration. The effects of $\mathrm{pH}$ and salinity on EUC are summarised in Fig. 4. The highest EUC was observed at a $\mathrm{pH}$ of 8.5 and salinity of $30 \%$, $234 \mathrm{mg} \mathrm{MSG} \mathrm{g}^{-1}$. $\mathrm{pH}$ had a significant effect on the EUC with the highest and lowest EUC at $\mathrm{pH}$ levels 8.5 and 7.5 , respectively $(p=0.04)$. The salinities of $30 \%$ resulted in a higher EUC compared to the other salinity levels, but this difference is not significant. Our

Table 2 Equations that were created by a quadratic model after taking into account all the results of the DoE. The equations can be used to make predictions about the response for given levels of each factor ( $\mathrm{pH}$ and salinity)

\begin{tabular}{|c|c|c|c|}
\hline Response & Equation & p-value & $\begin{array}{l}\text { Lack of fit } \\
\text { p-value }\end{array}$ \\
\hline Growth rate $\left(\right.$ day $\left.^{-1}\right)$ & $\begin{array}{l}-2.707+0.081 * \text { salinity }+0.7 * \mathrm{pH}+0.004 * \text { salinity } * \mathrm{pH}-0.002 * \text { salinity }^{2}- \\
0.058 * \mathrm{pH}^{2}\end{array}$ & 0.0084 & 0.3479 \\
\hline Productivity (g dry weight $\mathrm{L}^{-1}$ dday $^{-1}$ ) & $-10.408+0.177 *$ salinity $+2.458 * \mathrm{pH}-0.003 *$ salinity $^{2}-0.17 * \mathrm{pH}^{2}$ & 0.0056 & 0.1372 \\
\hline $\begin{array}{l}\text { Biomass yield on light ( } \mathrm{g} \text { dry weight } \\
\mathrm{mol}^{-1} \text { photons) }\end{array}$ & $-4.838+0.094 *$ salinity $+1.125 * \mathrm{pH}-0.002 *$ salinity $^{2}-0.078 * \mathrm{pH}^{2}$ & 0.0055 & 0.1950 \\
\hline Phycoerythrin (\% of dry weight) & $\begin{array}{l}89.845-1.077 * \text { salinity }-18.777 * \mathrm{pH}+0.033 * \text { salinity*pH }+0.014 * \text { salin- } \\
\text { ity }^{2}+1.2 * \mathrm{pH}^{2}\end{array}$ & 0.0003 & 0.3412 \\
\hline
\end{tabular}


model predicts the maximum EUC at $31 \%$ salinity, and $\mathrm{pH}$ levels out of range of the design, above 9 .

\section{Discussion}

This study investigated the variability in growth and biochemical composition of $R$. salina as an effect of salinity and $\mathrm{pH}$. $R$. salina was successfully cultivated in a range of salinity and $\mathrm{pH}$ under continuous conditions with high productivity, $>0.5 \mathrm{~g}$ dry weight $\mathrm{L}^{-1} \mathrm{day}^{-1}$. A clear optimal growth was observed in a combination of salinity and $\mathrm{pH}$, while the slowest growth was observed at the edges of the experimental design.

\section{Growth}

Studies have reported that the growth rate of $R$. salina ranges between 0.75 and 1.2 day $^{-1}$ (Bartual et al. 2002; ValenzuelaEspinoza 2005; Lafarga-De la Cruz et al. 2006; Jepsen et al. 2019; Yamamoto et al. 2020). However, it is noteworthy that this range of growth rate is observed in batch culture experiments, meaning that it is the maximum growth rate. In our study, the growth rate was determined by the dilution, hence not the maximum but the constant growth rate was studied. A limited body of literature exists on the growth of $R$. salina under continuous cultivation ( Vu et al. 2019; Thoisen et al. 2020). These studies were performed in larger scale and the growth rate did not exceed the $0.52 \mathrm{day}^{-1}$ in a maximum cell density of $2.5 \times 10^{6}$ cells $\mathrm{mL}^{-1}$. Oostlander et al. (2020) did demonstrate constant growth rates on $R$. salina in continuous flat plate photobioreactors, which were around $0.98 \mathrm{day}^{-1}$. This value is higher than the values of our research, $0.88 \mathrm{day}^{-1}$. This difference can be explained by the contrast in turbidity settings of our reactors as compared to the study of Oostlander et al. (2020). A more accurate comparison of the growth between the two studies can be performed by comparing the biomass production rate, after taking into account the biomass concentration in the reactor. The highest biomass production rate in this study was observed in a salinity of $30 \%$ o and a $\mathrm{pH}$ of 7.5, $1.17 \mathrm{~g} \mathrm{~L}^{-1} \mathrm{day}^{-1}$. Likewise, Oostlander et al. (2020), under similar light intensity, salinity and $\mathrm{pH}$ conditions, reported a biomass production rate of $1.04 \mathrm{~g} \mathrm{~L}^{-1} \mathrm{day}^{-1}$. A previous study on continuous cultivation of $R$. salina in the Algaemist-S system presented a constant maximum growth rate of $0.73 \mathrm{day}^{-1}$ in lower light intensity of blue light (Latsos et al. 2021).

The optimum growth rate of $R$. salina was observed in salinity of $30 \%$. This observation is compatible with the study of Jepsen et al. (2019), which confirms the wide salinity tolerance of $R$. salina from 5 to $50 \%$, with a maximum growth rate of 1.13 day $^{-1}$ at $29.1 \%$.
This study illustrated a significant effect of $\mathrm{pH}$ on the growth of $R$. salina. Although the strain was able to grow at the full range of $\mathrm{pH}, 6.5-8.5$, our model predicted a maximum growth at $\mathrm{pH}$ 6.9. This result is analogous to the literature. For example, Berge et al. (2010) demonstrated that $R$. marina could tolerate wide $\mathrm{pH}$ fluctuations, namely, from $\mathrm{pH} 4.4$ to 9.6, and maintained the maximum growth and production rate down to $\mathrm{pH} 7$. In contrast, our study showed that the growth of $R$. salina was significantly lower at $\mathrm{pH} 8.5$. This latter finding is in good agreement with the study of Hansen (2002), who demonstrated that the growth rate of $R$. salina significantly decreased at $\mathrm{pH} 9$. The lower growth in low $\mathrm{pH}$ can be explained by the fact that in microalgae, low $\mathrm{pH}$ values increase the maintenance energy requirements, by affecting solute transport and cell membrane/wall biosynthesis (Kallas and Castenholz 1982). In contrast, higher $\mathrm{pH}$ values may inhibit the growth by limiting the availability of the $\mathrm{pH}$ (Chenl and Durbin 1994).

\section{Phycoerythrin}

The phycoerythrin concentration that was obtained in this study is in line with the reported values of previous literature (Latsos et al. 2021). The phycoerythrin concentration was higher in conditions, which were not favourable for $R$. salina, with a peak in salinity of $40 \%$. An explanation for this phenomenon is illustrated in Fig. 5, where the phycoerythrin concentration is plotted against the biomass productivity of $R$. salina. According to Fig. 5, the phycoerythrin concentration is inversely proportional to the biomass productivity. There is extensive literature that emphasises the change of photosynthetic activity under salt stress of microalgae. Most microalgae reduce their photosynthetic activity due to the production of reactive oxygen species (ROS) and

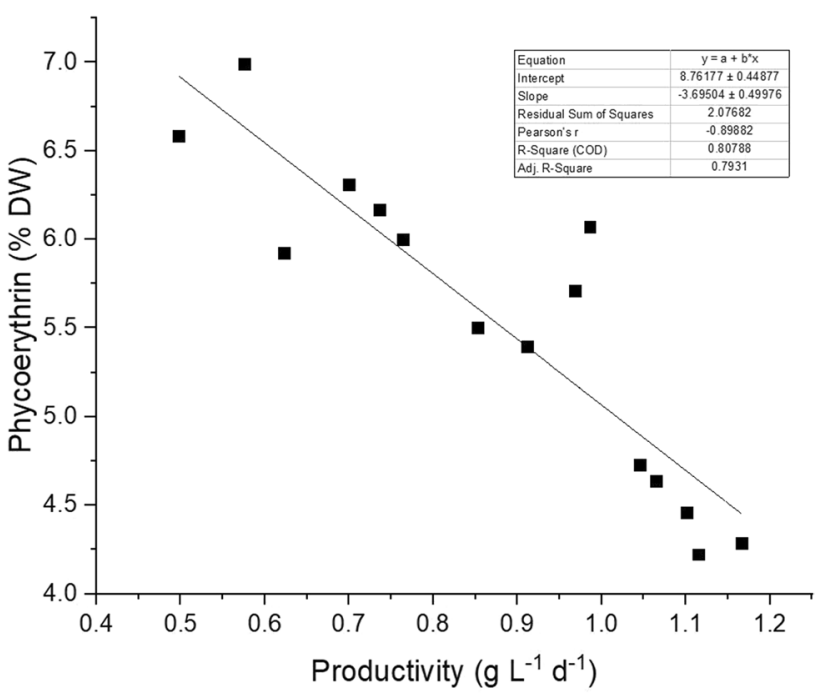

Fig. 5 Correlation of phycoerythrin (\% of dry weight) with growth (g dry weight $\mathrm{L}^{-1}$ day $^{-1}$ ) of $R$. salina 
Table 3 Free amino acid and nucleotide concentration (abbreviations explained in the text), and equivalent umami concentration (EUC) of $R$. salina under different combinations of salinity and $\mathrm{pH}$ conditions.
All data are expressed as the average of triplicate measurements. The standard deviation was less than $10 \%$

\begin{tabular}{|c|c|c|c|c|c|c|c|c|c|c|c|c|c|c|c|}
\hline \multirow{2}{*}{$\begin{array}{l}\mathrm{pH} \\
\text { Salinity }\end{array}$} & \multicolumn{5}{|l|}{6.5} & \multicolumn{6}{|l|}{7.5} & \multicolumn{4}{|l|}{8.5} \\
\hline & 20 & 25 & 30 & 35 & 40 & 20 & 25 & 30 & 30 & 30 & 35 & 20 & 25 & 30 & 40 \\
\hline \multicolumn{16}{|c|}{ Free amino acid $\left(\mathrm{mg} \mathrm{g}^{-1}\right)$} \\
\hline L-Asp & 0.21 & 0.15 & 0.25 & 0.15 & 0.20 & 0.32 & 0.12 & 0.14 & 0.55 & 0.63 & 0.15 & 0.23 & 0.18 & 0.52 & 0.28 \\
\hline -Glu & 4.35 & 4.92 & 6.58 & 2.50 & 3.11 & 4.36 & 0.73 & 4.00 & 3.56 & 4.43 & 2.21 & 5.17 & 5.26 & 6.86 & 4.36 \\
\hline -Asn & 0.40 & 0.44 & 1.15 & 0.68 & 0.74 & 0.41 & 0.17 & 0.49 & 0.55 & 0.67 & 0.36 & 0.42 & 0.47 & 0.71 & 0.73 \\
\hline -Ser & 0.36 & 0.29 & 0.54 & 0.18 & 0.27 & 0.37 & 0.10 & 0.25 & 0.58 & 0.72 & 0.27 & 0.53 & 0.28 & 0.64 & 0.35 \\
\hline -Gln & 0.95 & 0.77 & 1.52 & 0.67 & 0.86 & 0.92 & 0.19 & 0.68 & 0.85 & 1.05 & 0.37 & 0.94 & 0.74 & 1.41 & 1.50 \\
\hline -His & 0.32 & 0.34 & 0.53 & 0.13 & 0.28 & 0.30 & 0.11 & 0.32 & 0.60 & 0.78 & 0.33 & 0.50 & 0.31 & 0.51 & 0.48 \\
\hline Gly & 0.38 & 0.33 & 0.61 & 0.20 & 0.29 & 0.45 & 0.07 & 0.27 & 0.69 & 0.84 & 0.24 & 0.65 & 0.38 & 0.80 & 0.40 \\
\hline _-Thr & 0.36 & 0.26 & 0.54 & 0.18 & 0.28 & 0.36 & 0.09 & 0.24 & 0.56 & 0.70 & 0.23 & 0.60 & 0.29 & 0.60 & 0.34 \\
\hline -Arg & 2.39 & 2.50 & 3.98 & 0.99 & 1.82 & 1.95 & 7.55 & 1.01 & 2.85 & 4.90 & 1.56 & 3.15 & 2.78 & 3.27 & 2.62 \\
\hline -Ala & 3.87 & 3.17 & 4.03 & 2.11 & 2.92 & 3.22 & 10.66 & 2.68 & 3.40 & 5.25 & 8.34 & 2.42 & 0.84 & 3.35 & 3.25 \\
\hline -Tyr & 0.54 & 0.52 & 0.82 & 0.22 & 0.46 & 0.70 & 0.20 & 0.38 & 1.45 & 1.81 & 0.45 & 1.03 & 0.46 & 1.08 & 0.67 \\
\hline -Cys & 0.57 & 0.55 & 1.02 & 0.32 & 0.60 & 1.01 & 0.15 & 0.24 & 1.05 & 1.17 & 0.30 & 1.18 & 0.57 & 1.21 & 0.58 \\
\hline L-Val & 0.46 & 0.43 & 0.76 & 0.22 & 0.39 & 0.62 & 0.19 & 0.36 & 1.21 & 1.53 & 0.51 & 1.02 & 0.51 & 1.11 & 0.65 \\
\hline L-Phe & 0.67 & 0.66 & 1.05 & 0.23 & 0.63 & 1.01 & - & - & 1.79 & 2.25 & 1.72 & 0.92 & 0.67 & 1.58 & 1.04 \\
\hline L-Ile & 0.24 & 0.23 & 0.35 & 0.12 & 0.19 & 0.31 & 0.10 & 0.21 & 0.74 & 0.88 & 0.23 & 0.63 & 0.27 & 0.61 & 0.36 \\
\hline L-Leu & 1.10 & 0.99 & 1.68 & 0.45 & 0.94 & 1.57 & 0.39 & 0.77 & 2.11 & 3.24 & 0.96 & 2.19 & 1.04 & 2.35 & 1.40 \\
\hline L-Lys & 1.12 & 1.02 & 1.79 & 0.40 & 0.67 & 0.98 & 0.57 & 0.62 & 2.51 & 3.51 & 1.48 & 2.24 & 1.09 & 1.83 & 1.02 \\
\hline L-Pro & 2.16 & 2.17 & 4.06 & 6.51 & 5.16 & 1.99 & 2.68 & 2.69 & 3.42 & 3.85 & 1.08 & 3.04 & 1.46 & 3.49 & 3.72 \\
\hline Total FAA & 20.45 & 19.74 & 31.26 & 16.26 & 19.81 & 20.85 & 24.07 & 15.35 & 28.47 & 38.21 & 20.79 & 26.86 & 17.60 & 31.93 & 23.75 \\
\hline \multicolumn{16}{|c|}{ Nucleotides $\left(\mathrm{mg} \mathrm{g}^{-1}\right)$} \\
\hline AMP & 0.62 & 0.62 & 0.53 & 0.38 & 0.56 & 1.24 & 0.48 & 0.73 & 0.99 & 1.04 & 0.57 & 1.26 & 0.71 & 0.96 & 0.72 \\
\hline GMP & 0.62 & 0.51 & 0.78 & 0.15 & 0.36 & 0.51 & 0.19 & 0.35 & 0.84 & 0.93 & 0.39 & 0.69 & 0.58 & 0.74 & 0.54 \\
\hline IMP & 0.95 & 0.80 & 1.25 & 0.13 & 0.52 & 0.60 & 0.18 & 0.36 & 1.11 & 1.17 & 0.51 & 0.81 & 0.67 & 0.87 & 0.67 \\
\hline EUC & 135.31 & 132.27 & 224.60 & 19.10 & 60.55 & 110.32 & 7.02 & 67.42 & 162.77 & 195.79 & 43.35 & 173.09 & 144.74 & 234.02 & 112.59 \\
\hline
\end{tabular}

osmotic stress (Sudhir and Murthy 2004; Shetty et al. 2019). In high salt conditions, ROS damage the light-harvesting complexes of photosystem I (PSI), while the proteins of photosystem II that are involved in oxygen evolution are also impaired (Subramanyam et al. 2010; Neelam and Subramanyam 2013). This decrease in photosynthetic activity, therefore, explains the lower growth rate in salt stress.

The increase of phycoerythrin concentration of $R$. salina at higher salinities can be explained as a mechanism to resist the loss of photosynthetic activity. Phycoerythrin is an antioxidant, and the increase indicates that the strain exhibits adaptation to environmental stress (Özen et al. 2018). Antioxidant pigments protect the light-harvesting complexes against ROS. This function of pigments has been obtained before in the carotenoids of Dunaliella sp., which induces the carotenoid production in response to salt stress (Ye et al. 2008). Similar phycobiliprotein accumulation as salt stress response has been described in Spirulina sp. and Gracilaria
Table 4 Equivalent umami concentration of $R$. salina in comparison with other marine species

\begin{tabular}{lll}
\hline Species & EUC $\left(\mathrm{g} \mathrm{MSG}(100 \mathrm{~g})^{-1}\right)$ & Reference \\
\hline Rhodomonas salina (microalgae) & $0.7-23.4$ & Present study \\
Eriocheir sinensis (Chinese mitten crab) & $2.1-5.4$ & (Chen and Zhang 2007) \\
Birgus latro (Coconut crab) & $2.1-5.4$ & (Sato et al. 2015) \\
Coilia ectenes (Anchovy) & $0.3-1.0$ & (Zheng et al. 2015) \\
Ostrea rivularis (Oyster) & $0.8-26.9$ & (Liu et al. 2013) \\
Crassostrea hongkongensis (Oyster) & $1.4-8.8$ & (Liu et al. 2020) \\
Meretrix meretrix (Clam) & 0.12 & (Wen et al. 2020) \\
\hline
\end{tabular}


gracilis (Kumar et al. 2010; Hifney et al. 2013; Özen et al. 2018).

$\mathrm{pH}$ values higher than 8 and lower than 7 exerted a negative effect on the growth of $R$. salina. Conversely, phycoerythrin was higher at $\mathrm{pH}$ of 6.5 and 8.5 compared to 7.5. Phycoerythrin is stable and retains its colour at $\mathrm{pH}$ range 4-8.4, based on its absorption spectrum, with the highest absorbance peak at pH 7.6 (Marraskuranto et al. 2019). However, more extensive $\mathrm{pH}$ changes can disrupt the structure of the chromophore and phycoerythrin is colourless above pH 9 (Munier et al. 2014). The literature on the effect of $\mathrm{pH}$ on cryptophytes is not extensive, but in cyanobacteria, the phycoerythrin content increases with the increase of $\mathrm{pH}$, obtaining a maximum at pH 8 (Poza-Carrión et al. 2001; Hemlata and Fatma 2009; Begum et al. 2016). Additionally, the alkaline conditions increase the concentrations of ROS and increase the possibility of cell damage (Liu et al. 2007). The increased phycoerythrin concentration at higher $\mathrm{pH}$ can be associated with the increase of ROS as an antioxidant response.

\section{FAAs, nucleotides, and EUC}

The main FAAs that were obtained are L-glutamic acid (Glu), L-alanine (Ala), L-proline (Pro), and L-arginine (Arg), which is in line with literature studies on Rhodomonas sp. (Seixas et al. 2009; van Houcke et al. 2017). These FAAs are also the most common in other Cryptophyceae as well (Martin-Jézéquel et al. 1988; Brown 1991). The total FAA concentration is not affected by the salinity. However, the L-proline concentration increases significantly with the increase of the salinity, from $2.5 \mathrm{mg} \mathrm{g}$ dry weight ${ }^{-1}$ at 20 $\%$ to $4.4 \mathrm{mg} \mathrm{g}$ dry weight ${ }^{-1}$ at $40 \%$. The accumulation of proline in algal cells in response to hyperosmotic stress has been reported in other studies (Schobert 1980; Reynoso and de Gamboa 1982). Proline has the ability to function as an osmotic regulator and restore the non-stress volume and turgor pressure (Shetty et al. 2019). In addition, proline is associated with the regulation of the cell's water structure, which protects the cell against dehydration in salt stress (Le Rudulier et al. 1984; Kendall 1996).

Despite the effect of salinity on the FAA concentration of $R$. salina, there is no significant change in the 5 '-nucleotide concentration associated with the salinity. Unlike salinity, $\mathrm{pH}$ changes affected the 5'-nucleotide concentration, showing a peak at $\mathrm{pH}$ 8.5. It is known that in low $\mathrm{pH}$, IMP, GMP, and AMP hydrolyse to their corresponding bases, hypoxanthine, guanine, and adenine, respectively (Golankiewicz et al. 1985). The aqueous hydrolysis rate of 5 '-nucleotides is double at pH 7 compared to $\mathrm{pH} 8$ (Shaoul and Sporns 1987).

The synergistic effect of the umami AAs and the flavour nucleotides in $R$. salina was evaluated by the EUC value. Due to the higher concentration of $5^{\prime}$-nucleotides at $\mathrm{pH} 8.5$, the EUC is also significantly higher at $\mathrm{pH} 8.5,234 \mathrm{mg} \mathrm{MSG}$ $\mathrm{g}^{-1}$. There is no literature to compare the EUC value of $R$. salina with other microalgae. However, the average EUC in $R$. salina was higher than the values that have been reported in many aquatic animals (Tables 3 and 4 ), which means that the umami taste of $R$. salina was intense.

\section{Conclusion}

In this study, using a D-optimal DoE, the effect of salinity and $\mathrm{pH}$ on growth, phycoerythrin, and non-volatile umami taste active compounds of $R$. salina was investigated. This microalga was able to adapt and grow sufficiently in a range of salinity and $\mathrm{pH}$, showing the highest growth at salinity 29 $\% o$ and $\mathrm{pH}$ 7. These results provide valuable information for the large-scale production of $R$. salina. Photopigment composition analysis illustrated that $R$. salina was rich in phycoerythrin when it was cultivated in conditions which were not favourable for the growth of the strain (i.e. high salinity and $\mathrm{pH})$. This increase of phycoerythrin can be explained by the antioxidant activity of the pigment, which is required under those conditions. The umami taste attribute was examined based on the estimation method of EUC. The EUC of $R$. salina was significantly affected by the $\mathrm{pH}$, with higher EUC at higher $\mathrm{pH}$ values. $R$. salina was rich in umami taste active compounds compared to other aquaculture species, suggesting that the characteristic taste of $R$. salina is suitable for use as an umami condiment.

In summary, in unfavourable growth conditions, $R$. salina accumulates compounds to protect itself. There is a trade-off between the growth and the quality of $R$. salina in terms of phycoerythrin and EUC. This trade-off has to be carefully balanced according to the desired biochemical composition of $R$. salina as an end product. An ideal system could be a two-stages $R$. salina production. An initial stage, where $R$. salina would be cultivated in the optimal conditions for growth, and a second stage, where the cultivation conditions would be favourable for the phycoerythrin production or the enhance of umami taste.

Supplementary Information The online version contains supplementary material available at https://doi.org/10.1007/s10811-021-02547-4.

Author contribution C. Latsos: conceptualisation, implementation, investigation, formal analysis, writing original draft, writing-review and editing. J. van Houcke: conceptualisation, writing - review and editing, supervision. T. Moerdijk: formal analysis, writing - review and editing. G. Bakratsas: implementation, formal analysis, writing - review and editing. K. R. Timmermans: conceptualisation, writing review and editing, supervision.

Funding This work was financially supported by ValgOrize project, funded by the INTERREG V 2 Seas Mers Zeeën program, with the financial support of the European Regional Development Fund. 
Data availability Full data available from the authors upon request.

\section{Declarations}

Conflict of interest The authors declare no competing interests.

Open Access This article is licensed under a Creative Commons Attribution 4.0 International License, which permits use, sharing, adaptation, distribution and reproduction in any medium or format, as long as you give appropriate credit to the original author(s) and the source, provide a link to the Creative Commons licence, and indicate if changes were made. The images or other third party material in this article are included in the article's Creative Commons licence, unless indicated otherwise in a credit line to the material. If material is not included in the article's Creative Commons licence and your intended use is not permitted by statutory regulation or exceeds the permitted use, you will need to obtain permission directly from the copyright holder. To view a copy of this licence, visit http://creativecommons.org/licenses/by/4.0/.

\section{References}

AL-Qasmi M, Raut N, Talebi S, Al-Rajhi S, Al-Barwani T (2012) A review of effect of light on microalgae growth. In: Proceedings of the World Congress on Engineering WCE 2012, London pp 1-3

Arndt C, Sommer U (2014) Effect of algal species and concentration on development and fatty acid composition of two harpacticoid copepods, Tisbe sp. and Tachidius discipes, and a discussion about their suitability for marine fish larvae. Aquac Nutr 20:44-59

Bartual A, Lubián LM, Gálvez JA, Niell FX (2002) Effect of irradiance on growth, photosynthesis, pigment content and nutrient consumption in dense cultures of Rhodomonas salina (Wislouch) (Cryptophyceae). Cienc Mar 28:381-392

Begum H, Yusoff FMD, Banerjee S, Khatoon H, Shariff M (2016) Availability and utilization of pigments from microalgae. Crit Rev Food Sci Nutr 56:2209-2222

Bennett A, Bogorad L (1973) Complementary chromatic adaptation in a filamentous blue-green alga. J Cell Biol 58:419-435

Berge T, Daugbjerg N, Andersen BB, Hansen PJ (2010) Effect of lowered $\mathrm{pH}$ on marine phytoplankton growth rates. Mar Ecol Prog Ser 416:79-91

Bishop WM, Zubeck HM (2012) Evaluation of microalgae for use as nutraceuticals and nutritional supplements. J Nutr Food Sci 2:5

Borowitzka MA (1998) Algae as food. In: Wood BJB (ed) Microbiology of Fermented Foods. Springer, Boston, pp 585-602

Breuer G, Lamers PP, Martens DE, Draaisma RB, Wijffels RH (2013) Effect of light intensity, $\mathrm{pH}$, and temperature on triacylglycerol (TAG) accumulation induced by nitrogen starvation in Scenedesmus obliquus. Bioresour Technol 143:1-9

Brown MR (1991) The amino-acid and sugar composition of 16 species of microalgae used in mariculture. J Exp Mar Bio Ecol 145:79-99

Brown MR, Jeffrey SW, Volkman JK, Dunstan GA (1997) Nutritional properties of microalgae for mariculture. Aquaculture 151:315-331

Chen DW, Zhang M (2007) Non-volatile taste active compounds in the meat of Chinese mitten crab (Eriocheir sinensis). Food Chem 104:1200-1205

Chenl CY, Durbin EG (1994) Effects of pH on the growth and carbon uptake of marine phytoplankton. Mar Ecol Prog Ser 109:83-94

Chu W-L (2013) Biotechnological applications of microalgae. IeJSME 6(Suppl 1):S24-S37

Coelho L, Prince J, Nolen T (1998) Processing of defensive pigment in Aplysia californica: acquisition, modification and mobilization of the red algal pigment, r-phycoerythrin by the digestive gland. J Exp Biol 201:425-42538

De Oliveira MACL, Monteiro MPC, Robbs PG, Leite SGF (1999) Growth and chemical composition of Spirulina maxima and Spirulina platensis biomass at different temperatures. Aquac Int 7:261-275

Doust AB, Wilk KE, Curmi PMG, Scholes GD (2006) The photophysics of cryptophyte light-harvesting. J Photochem Photobiol A $184: 1-17$

Fábregas J, Maseda A, Domínguez A, Ferreira M, Otero A (2002) Changes in the cell composition of the marine microalga, Nannochloropsis gaditana, during a light:dark cycle. Biotechnol Lett 24:1699-1703

Fuke S, Konosu S (1991) Taste-active components in some foods: a review of Japanese research. Physiol Behav 49:863-868

Fuke S, Ueda Y (1996) Interactions between umami and other flavor characteristics. Trends Food Sci Technol 7:407-411

Golankiewicz B, Zielonacka-Lis E, Wojciech F (1985) Kinetics and mechanism of the acid-catalyzed hydrolysis of a hypermodified nucleoside wyosine and its 5'-monophosphate. Nucleic Acids Res 13:8019-8033

Gonzalez Araya R, Mingant C, Petton B, Robert R (2012) Influence of diet assemblage on Ostrea edulis broodstock conditioning and subsequent larval development. Aquaculture 364-365:272-280

Guevara M, Bastardo L, Cortez R, Arredondo-Vega B, Romero L, Gómez P (2011) Rhodomonas salina (Cryptophyta) pastes as feed for Brachionus plicatilis (Rotifera). Rev Biol Trop 59:1503-1515 (In Spanish)

Guillard RRL, Hargraves PE (1993) Stichochrysis immobilis is a diatom, not a chrysophyte. Phycologia 32:234-236

Hansen PJ (2002) Effect of high pH on the growth and survival of marine phytoplankton: Implications for species succession. Aquat Microb Ecol 28:279-288

Hemlata FT (2009) Screening of cyanobacteria for phycobiliproteins and effect of different environmental stress on its yield. Bull Environ Contam Toxicol 83:509-515

Hifney A, Issa AA, Fawzy M (2013) Abiotic stress induced production of $\beta$-carotene, allophycocyanin and total lipids in Spirulina sp. J Biol Earth Sci 3:54-64

Hudek K, Davis LC, Ibbini J, Erickson L (2014) Commercial products from algae. In: Bajpai R, Prokop A, Zappi M (eds) Algal Biorefineries, vol 1. Cultivation of Cells and Products. Springer, Dordrecht, pp 275-295

Jepsen PM, Thoisen CV, Carron-Cabaret T, Pinyol-Gallemí A, Nielsen SL, Hansen BW (2019) Effects of salinity, commercial salts, and water type on cultivation of the cryptophyte microalgae Rhodomonas salina and the calanoid copepod Acartia tonsa. J World Aquac Soc 50:104-118

Kallas T, Castenholz RW (1982) Internal pH and ATP-ADP pools in the cyanobacterium Synechococcus sp. during exposure to growth-inhibiting low pH. J Bacteriol 149:229-236

Kawai M, Okiyama A, Ueda Y (2002) Taste enhancements between various amino acids and IMP. Chem Senses 27:739-745

Kendall L (1996) The osmotic adjustment of marine microalgae and the complex role osmolytes play in this process. Masters Thesis, The University of Groningen

Khatoon N, Pal R (2015) Microalgae in biotechnological application: a commercial approach. In: Bahadur B, Rajam MV, Sahijram L, Krisnamurthy KV (eds) Plant biology and biotechnology: Volume II: Plant genomics and biotechnology. Springer, New Delhi pp 27-47

Koyande AK, Chew KW, Rambabu K, Tao Y, Chu DT, Show PL (2019) Microalgae: a potential alternative to health supplementation for humans. Food Sci Hum Wellness 8:16-24

Kumar M, Kumari P, Gupta V, Reddy CRK, Jha B (2010) Biochemical responses of red alga Gracilaria corticata (Gracilariales, 
Rhodophyta) to salinity induced oxidative stress. J Exp Mar Bio Ecol 391:27-34

Lafarga-De la Cruz F, Valenzuela-Espinoza E, Millán-Núñez R, Trees CC, Santamaría-del-Ángel E, Núñez-Cebrero F (2006) Nutrient uptake, chlorophyll $a$ and carbon fixation by Rhodomonas sp. (Cryptophyceae) cultured at different irradiance and nutrient concentrations. Aquac Eng 35:51-60

Latsos C, Van HJ, Blommaert L, Verbeeke GP, Kromkamp J, Timmermans KR (2021) Effect of light quality and quantity on productivity and phycoerythrin concentration in the cryptophyte Rhodomonas sp. J Appl Phycol 33:729-741

Latsos C, Van HJ, Timmermans KR (2020) The effect of nitrogen starvation on biomass yield and biochemical constituents of Rhodomonas sp. Front Mar Sci 7:563333

Lawrenz E, Fedewa EJ, Richardson TL (2011) Extraction protocols for the quantification of phycobilins in aqueous phytoplankton extracts. J Appl Phycol 23:865-871

Le Rudulier D, Strom AR, Dandekar AM, Smith LT, Valentine RC (1984) Molecular biology of osmoregulation. Science 224:1064-1068

Liu C, Ji W, Jiang H, Shi Y, He L, Gu Z, Zhu S (2020) Comparison of biochemical composition and non-volatile taste active compounds in raw, high hydrostatic pressure-treated and steamed oysters Crassostrea hongkongensis. Food Chem 344:128632

Liu TT, Xia N, Wang QZ, Chen DW (2019) Identification of the non-volatile taste-active components in crab sauce. Foods 8:324

Liu W, Au DWT, Anderson DM, Lam PKS, Wu RSS (2007) Effects of nutrients, salinity, $\mathrm{pH}$ and light:dark cycle on the production of reactive oxygen species in the alga Chattonella marina. J Exp Mar Bio Ecol 346:76-86

Liu Y, Qiu C (2016) Calculated taste activity values and umami equivalences explain why dried sha-chong (Sipunculus nudus) is a valuable condiment. J Aquat Food Prod Technol 25:177-184

Liu Y, Zhang C, Chen S (2013) Comparison of active non-volatile taste components in the viscera and adductor muscles of oyster (Ostrea rivularis Gould). Food Sci Technol Res 19:417-424

Marraskuranto E, Raharjo TJ, Kasiamdari RS, Nuringtyas TR (2018) Influence of salinity on growth and phycoerythrin production of Rhodomonas salina. Squalen Bull Mar Fish Postharvest Biotechnol 13:109

Marraskuranto E, Raharjo TJ, Kasiamdari RS, Nuringtyas TR (2019) Color stability of phycoerythrin crude extract (PECE) from Rhodomonas salina toward physicochemical factors. Squalen Bull Mar Fish Postharvest Biotechnol 14:21-31

Martin-Jézéquel V, Poulet S, Harris R, Moal J, Samain J (1988) Interspecific and intraspecific composition and variation of free amino acids in marine phytoplankton. Mar Ecol Prog Ser 44:303-313

Mau JL (2005) The umami taste of edible and medicinal mushrooms. Int J Med Mushrooms 7:119-125

Mulders KJM, Lamers PP, Martens DE, Wijffels RH (2014) Phototrophic pigment production with microalgae: biological constraints and opportunities. J Phycol 50:229-242

Munier M, Jubeau S, Wijaya A, Morançais M, Dumay J, Marchal L, Jaouen P, Fleurence J (2014) Physicochemical factors affecting the stability of two pigments: R-phycoerythrin of Grateloupia turuturu and B-phycoerythrin of Porphyridium cruentum. Food Chem 150:400-407

Neelam S, Subramanyam R (2013) Alteration of photochemistry and protein degradation of photosystem II from Chlamydomonas reinhardtii under high salt grown cells. J Photochem Photobiol B 124:63-70

Ninomiya Y, Kurenuma S, Nomura T, Uebayashi H, Kawamura H (1992) Taste synergism between monosodium glutamate and 5'-ribonucleotide in mice. Comp Biochem Physiol 101A:97-102

Nishimura T, Kato H (2009) Taste of free amino acids and peptides. Food Rev Int 37-41
Oostlander PC, van Houcke J, Wijffels RH, Barbosa MJ (2020) Optimization of Rhodomonas sp. under continuous cultivation for industrial applications in aquaculture. Algal Res 47:101889

Özen M, Kozak A, Dere Ş, Tüney Kızılkaya İ (2018) The effects of different salt concentrations on the biochemical contents of Gracilaria gracilis Greville (Rhodophyta). Celal Bayar Üniversitesi Fen Bilim Derg 14:303-307

Poza-Carrión C, Fernández-Valiente E, Piñas FF, Leganés F (2001) Acclimation of photosynthetic pigments and photosynthesis of the cyanobacterium Nostoc sp. strain UAM206 to combined fluctuations of irradiance, $\mathrm{pH}$, and inorganic carbon availability. J Plant Physiol 158:1455-1461

Renaud SM, Van TL, Parry DL (1999) The gross chemical composition and fatty acid composition of 18 species of tropical Australian microalgae for possible use in mariculture. Aquaculture 170:147-159

Reynoso GT, de Gamboa BA (1982) Salt tolerance in the freshwater algae. Comp Biochem Physiol 73:95-99

Richmond A (ed) (2004) Handbook of Microalgal Culture: Biotechnology and Applied Phycology. Blackwell Science, Oxford

Riisgård HU, Egede PP, Barreiro Saavedra I (2011) Feeding behaviour of the mussel, Mytilus edulis : New observations, with a minireview of current knowledge. J Mar Sci 2011:312459

Sato T, Ohgami, Kaneniwa SM (2015) Seasonal variations in free amino acids, nucleotide-related compounds, and fatty acids and meat yield of the coconut crab Birgus latro. Fish Sci 81:959-970

Schobert B (1980) Proline catabolism, relaxation of osmotic strain and membrane permeability in the diatom Phaeodactylum tricornutum. Physiol Plant 50:37-42

Seixas P, Coutinho P, Ferreira M, Otero A (2009) Nutritional value of the cryptophyte Rhodomonas lens for Artemia sp. J Exp Mar Biol Ecol 381:1-9

Shallenberger R (1993) Taste of amino acids. In: Taste Chemistry. Chapman \& Hall, London pp 226-233

Shaoul O, Sporns P (1987) Hydrolytic stability at intermediate $\mathrm{pHs}$ of the common purine nucleotides in food, inosine- $5^{\prime}$ monophosphate, guanosine-5'-monophosphate and adenosine5'-monophosphate. J Food Sci 52:810-812

Shetty P, Gitau MM, Maróti G (2019) Salinity stress responses and adaptation mechanisms in eukaryotic green microalgae. Cells 8:e8121657

Spolaore P, Joannis-Cassan C, Duran E, Isambert A (2006) Commercial applications of microalgae. J Biosci Bioeng 101:87-96

Subramanyam R, Jolley C, Thangaraj B, Nellaepalli S, Webber AN, Fromme P (2010) Structural and functional changes of PSI-LHCI supercomplexes of Chlamydomonas reinhardtii cells grown under high salt conditions. Planta 231:913-922

Sudhakar MP, Jagatheesan A, Perumal K, Arunkumar K (2015) Methods of phycobiliprotein extraction from gracilaria crassa and its applications in food colourants. Algal Res 8:115-120

Sudhir P, Murthy SDS (2004) Effects of salt stress on basic processes of photosynthesis. Photosynthetica 42:481-486

Thoisen C, Pedersen JS, Jørgensen L, Kuehn A, Hansen BW, Nielsen SL (2020) The effect of cell density on biomass and fatty acid productivity during cultivation of Rhodomonas salina in a tubular photobioreactor. Aquac Res 51:3367-3375

Thompson P (1999) The response of growth and biochemical composition to variations in daylength, temperature, and irradiance in the marine diatom Thalassiosira pseudonana (Bacillariophyceae). J Phycol 35:1215-1223

Valenzuela-Espinoza E (2005) Growth, nutrient uptake and proximate composition of Rhodomonas sp cultured using f/2 medium and agricultural fertilizers. Cienc Mar 31:79-89

van Houcke J, Medina I, Maehre HK, Cornet J, Cardinal M, Linssen J, Luten J (2017) The effect of algae diets (Skeletonema costatum and Rhodomonas baltica) on the biochemical composition and 
sensory characteristics of Pacific cupped oysters (Crassostrea gigas) during land-based refinement. Food Res Int 100:151-160

Varfolomeev SD, Wasserman LA (2011) Microalgae as source of biofuel, food, fodder, and medicines. Appl Biochem Microbiol 47:789-807

Vu MTT, Douëtte C, Rayner TA, Thoisen C, Nielsen SL, Hansen BW (2016) Optimization of photosynthesis, growth, and biochemical composition of the microalga Rhodomonas salina - an established diet for live feed copepods in aquaculture. J Appl Phycol 28:1485-1500

Vu MTT, Jepsen PM, Jørgensen NOG, Hansen BW, Nielsen SL (2019) Testing the yield of a pilot-scale bubble column photobioreactor for cultivation of the microalga Rhodomonas salina as feed for intensive calanoid copepod cultures. Aquac Res 50:63-71

Watanabe K, Lan H-L, Yamaguchi K, Konosu S (1990) Taste-active components of scallop Part II. Role of extractive components of scallop in its characteristic taste development. Nippon Shokuhin Kogyo Gakkaishi 37:439-445

Wen X, Chen A, Wu Y, Yang Y, Xu Y, Xia W, Zhang Y, Cao Y, Chen $S$ (2020) Comparative evaluation of proximate compositions and taste attributes of three Asian hard clams (Meretrix meretrix) with different shell colors. Int J Food Prop 23:400-411
Yamaguchi K (1996) Recent advances in microalgal bioscience in Japan, with special reference to utilization of biomass and metabolites: a review. J Appl Phycol 8:487-502

Yamaguchi S, Tomoko Y, Shingo I, Tsunehiko N (1971) Measurement of the relative taste intensity of some $\mathrm{L}-\alpha$-amino acids and 5'-nucleotides. J Food Sci 36:846-849

Yamamoto S, Bossier P, Yoshimatsu T (2020) Biochemical characterization of Rhodomonas sp. Hf-1 strain (cryptophyte) under nitrogen starvation. Aquaculture 516:734648

Ye ZW, Jiang JG, Wu GH (2008) Biosynthesis and regulation of carotenoids in Dunaliella: progresses and prospects. Biotechnol Adv $26: 352-360$

Zhao CJ, Schieber A, Gänzle MG (2016) Formation of taste-active amino acids, amino acid derivatives and peptides in food fermentations - a review. Food Res Int 89:39-47

Zheng J-Y, Tao N-P, Gong J, Gu S-Q, Xu C-H (2015) Comparison of non-volatile taste-active compounds between the cooked meats of pre- and post-spawning Yangtze Coilia ectenes. Fish Sci 81:559-568

Publisher's note Springer Nature remains neutral with regard to jurisdictional claims in published maps and institutional affiliations. 